九州大学学術情報リポジトリ

Kyushu University Institutional Repository

\title{
First Identification of the Causal Mutation for Coagulation F11 Deficiency in Hanwoo Cattle
}

$\mathrm{CHO}$, Sung Hyun

Division of Animal and Dairy Science, Chungnam National University

SE0, Dongwon

Division of Animal and Dairy Science, Chungnam National University

GANBOLD, Onolragchaa

Division of Animal and Dairy Science, Chungnam National University

CHOI, Nu Ri

Division of Animal and Dairy Science, Chungnam National University

他

https://doi.org/10.5109/2232276

出版情報：九州大学大学院農学研究院紀要. 64 (1)，pp.55-59，2019-02-28. Faculty of Agriculture， Kyushu University

バージョン :

権利関係 : 


\title{
First Identification of the Causal Mutation for Coagulation F11 Deficiency in Hanwoo Cattle
}

\author{
Sung Hyun $\mathrm{CHO}^{1}$, Dongwon $\mathrm{SEO}^{1}$, Onolragchaa GANBOLD ${ }^{1}, \mathrm{Nu}_{\mathrm{Ri}} \mathrm{CHOI}^{1}$, \\ Prabuddha MANJULA ${ }^{1}$, Shil JIN ${ }^{1}$, Seung Hwan LEE ${ }^{1}$, Nobuhiko YAMAUCHI, \\ Takafumi GOTOH ${ }^{2}$ and Jun Heon LEE ${ }^{1}$
}

\author{
Department of Animal and Marine Bioresource Science, Faculty of Agriculture, \\ Kyushu University, Fukuoka, 819-0395, Japan, \\ (Received October 5, 2018 and accepted November 12, 2018)
}

\begin{abstract}
Plasma thromboplastin antecedent (factor XI or F11) deficiency is a relatively mild hemorrhagic genetic disorder reported in Holstein and Japanese black cattle that is caused by two insertional mutations. In this study, we identified a causal mutation of F11 deficiency in Hanwoo cattle and developed a more efficient method to identify this mutation. A total of 2,043 Hanwoo samples from 35 farms, representing three regions (Yeongam, Haman, Yanggu) were used in this study. The mutation is caused by the insertion of 15 bp at exon 9 of the F11 gene; the same mutation has been described in Japanese black cattle. In addition, the gene frequency of F11 deficiency was $1.52 \%$ in the Hanwoo cattle population, and all mutant alleles appeared in the heterozygous animals. Especially, this result suggests that $15 \mathrm{bp}$ insertion might be caused by a semi-embryonic lethal gene, which could affect the Hanwoo population. Although, the proportion of the disorder allele is low, the system for verifying this deficiency and additional phenotypic symptoms are needed to prevent any kind of losses in Hanwoo industry. Also the novel TaqMan assay genotyping method for the identification of F11 deficiency proposed in this study offers rapid and accurate results and may be efficiently applied in Hanwoo breeding programs.
\end{abstract}

Key words: Factor XI, Hanwoo, Genetic disorder, TaqMan genotyping

\section{INTRODUCTION}

Plasma thromboplastin antecedent (factor XI or F11) is a plasma serine proteolytic coenzyme involved in the early stage of blood coagulation reactions. The cattle F11 gene is located on bovine chromosome 27 (BTA27) and consists of 15 exons and 14 introns. The structure of F11 is composed of two types of homodimers (heavy chain and light chain) linked by a disulfide bond (Bouma and Griffin, 1977). The heavy chain homodimers comprise four Apple domains, which have binding sites for F9, F12, thrombin, and high-weight kininogen (Baglia et al., 1990, 1993; Baglia and Walsh, 1996; Sun and Gailani, 1996). Of these, F11 is converted into an activated form by F12, which performs a series of roles to activate $\mathrm{F} 9$.

F11 deficiency has been reported in several mammals including humans, dogs, and cattle, which inherit it in the recessive autosomal form (Dodds and Kull, 1971; Gentry et al., 1975; Kociba et al., 1969). Other than hemophilia, the symptoms of F11 deficiency are relatively mild. Rare consequences of F11 deficiency include natural hemorrhage and joint bleeding. In cattle, the causative mutation of F11 deficiency can be classified into two types. F11 deficiency reported in Japanese black cattle (Type I) is caused by the insertion of $15 \mathrm{bp}$

${ }^{1}$ Division of Animal and Dairy Science, Chungnam National University, Daejeon 34134, Korea

${ }^{2}$ Department of Agricultural Sciences and Natural Resources, Faculty of Agriculture, Kagoshima University, Kagoshima 8900065, Japan

* Corresponding author (E-mail: junheon@cnu.ac.kr) in the exon 9 region and a single nucleotide polymorphism (SNP) located at the end of the insertion site in the F11 gene, which is converted from adenine to cytosine in the amino acid sequence (Takasu et al., 2005). A mutation identified in Holstein cattle (Type II) is caused by a stop codon resulting from a 76-bp insertion in the F11 gene at exon 12 (Marron et al., 2004).

Although some studies have been conducted on genetic diseases in Hanwoo cattle, genetic disease monitoring systems have not yet been established (Chung et al., 2005). Therefore, relatively mild genetic diseases, such as F11 deficiency, cannot be identified in Hanwoo cattle. In addition, Hanwoo breeding systems have been extensively used across Korea to select proven bulls through progeny tests and artificial insemination. Thus, it is necessary to identify carrier animals, even when they have normal phenotypes, to ensure the removal of defective alleles from the entire Hanwoo population. Therefore, the purpose of this study was to identify F11 deficiency in Hanwoo cattle and to determine the status of F11 deficiency on farms.

\section{MATERIALS AND METHODS}

\section{Animals and preparation of genomic DNA sam- ples}

Animals was made up at the Hanwoo Farm in Yeongam County (10 farms; 776 animals), in Haman County (15 farms; 822 animals) and in Yanggu (10 farms; 445 animals). Total 2,043 of blood samples were used for this experiment.

Blood samples prepared for DNA extraction was centrifuged at a speed of $300 \mathrm{~g}$ to separate the leukocyte 
layer located in the buffy coat. DNA extraction was performed on the separated leukocyte layer using two methods. First, gDNA was extracted using the PrimePrep ${ }^{\mathrm{TM}}$ genomic DNA isolation kit (Genetbio, Korea) as a method for extracting genomic DNA (gDNA) using a general DNA extraction kit. The concentration and quality of the extracted DNA were measured using a Nanodrop 2000 c spectrophotometer (Thermo Scientific, USA). DNA samples that underwent QC procedures were subjected to $25 \mathrm{ng} / \mu \mathrm{L}$ dilution for the same PCR amplification. Second, gDNA was extracted using PrimePrep Direct PCR Reagent (Genetbio, Korea) to simplify the DNA extraction process and to test the rapid and easy genotyping process. In this method, $5 \mu \mathrm{l}$ of leukocyte layer and $100 \mu \mathrm{l}$ of Reagent solution were mixed at a ratio of 1:20, and the reaction time was 10 minutes at $95^{\circ} \mathrm{C}$. After that, the supernatant was obtained by centrifugation and diluted 20 times to perform Taq Man assay genotyping.

\section{PCR amplification and genotyping}

We designed and used three pairs of primers specific to the mutation site of the F11 gene to identify the cause mutation of the F11 deficiency in Hanwoo (Table 1) and PCR (polymerase chain reaction) amplification was used to confirm the genotype.

A genotyping was carried out through electrophoresis to check indels of PCR amplification product. F11 deficiency mutations proceeded only by simple electrophoresis without additional treatment and restriction enzyme as insertion mutation.

\section{Sequencing and TaqMan assay genotyping}

PCR sequence data was obtained by direct sequencing (www.cosmogentech.co.kr) of the PCR products that were purified from 10 normal animals and 3 carrier animals. The obtained sequence information was analyzed using BioEdit Sequence Alignment Editor program (BioEdit, USA).

TaqMan assay genotyping was performed by specific probe assay that was designed for identify F11 indel region in Hanwoo. Genotyping was performed by using a Bio-Rad real-time PCR machine (Bio-Rad, USA) to isolate mutant and normal individuals as fluorescence colors of VIC and FAM, respectively.

\section{RESULTS AND DISCUSSION}

To identify the causative mutation of F11 deficiency, 376 Hanwoo samples were initially subjected to polymerase chain reaction (PCR) amplification and electrophoresis using a specific primer set that identified Type I and Type II mutations. The Type II deficiency mutation was not detected in the Hanwoo population. However, normal animals with the Type I mutation showed only one PCR fragment (342 bp), whereas carrier animals showed two different PCR fragments (179 and $342 \mathrm{bp}$ ) resulting from a 15-bp insertional mutation (Figure 1). To confirm these results, we performed direct sequencing of the carrier animals and found that the results matched those of mutant alleles in Japanese black cattle. Lim et al. (Lim et al., 2016) previously investigated Type II F11 deficiency in 78 proven Hanwoo bulls and found no mutations, consistent with the results of the current study. Kim et al. (Kim et al., 2002) examined the genetic distances among Hanwoo, Holstein, and Japanese black cattle using 13 highly polymorphic microsatellite markers and determined that Hanwoo and Japanese black cattle were clustered together, whereas the Holstein breed clustered separately. Similarly, a principal components analysis (PCA) using 58 SNP makers to assess the genetic diversity of cattle revealed that Japanese black cattle were genetically more closely related to Hanwoo than Holstein cattle (Lin et al., 2010). The Type I mutation identified in the current study may support the close relationships found between Hanwoo and Japanese black cattle in these previous studies.

F11 deficiency in Holstein cattle has been reported to prolong the reproductive cycle due to the retardation of luteal atrophy caused by weakness in follicular development during the estrous cycle (Liptrap et al., 1995), and has been associated with low fertility in animals

Table 1. Primer pair information for F11 indel identification in two kinds of exon area and Taq Man probe information for F11 mutation identification in Hanwoo

\begin{tabular}{|c|c|c|c|c|c|c|}
\hline Marker & Gene & Location & Region & $\begin{array}{l}\text { Primer } \\
\text { (Forward/Reverse) } \\
\left(5,-3{ }^{\prime}\right)\end{array}$ & $\begin{array}{l}\text { Amplicon } \\
\text { (bp) }\end{array}$ & $\begin{array}{l}\text { annealing temp } \\
\left({ }^{\circ} \mathrm{C}\right)\end{array}$ \\
\hline Primer1 & \multirow{3}{*}{$\begin{array}{l}\text { Coagulation } \\
\text { factor } 11 \\
\text { gene }\end{array}$} & $\begin{array}{l}\text { g.15367049-124- } \\
\text { (76bp insert) }\end{array}$ & Exon 12 & $\begin{array}{l}\text { AGCGGCATTTTGAATCAATC/ } \\
\text { ATGGACTGAAAGGGGAGCTT }\end{array}$ & 287 & 53 \\
\hline Primer2 & & \multirow{2}{*}{$\begin{array}{l}\text { g.15362363-77- } \\
\text { (15bp insert) }\end{array}$} & Exon9 & $\begin{array}{l}\text { ACTTTCAAAATGGGAACTCCTTCC/ } \\
\text { ATGGCAGAACACTGCACAGC }\end{array}$ & 342 & 64 \\
\hline Primer3 & & & Exon9 & $\begin{array}{l}\text { TGCTGTGCAGTGTTATATGTGC/ } \\
\text { TTGCACGATTCTTGAGATGG }\end{array}$ & 179 & 64 \\
\hline \multirow{2}{*}{$\begin{array}{l}\text { Taq Man } \\
\text { Assay } \\
\text { probe }\end{array}$} & \multirow{2}{*}{$\begin{array}{l}\text { Coagulation } \\
\text { factor } 11 \\
\text { gene }\end{array}$} & \multirow{2}{*}{$\begin{array}{l}\text { g.15362363-77- } \\
\text { (15bp insert) }\end{array}$} & \multirow[t]{2}{*}{ Exon9 } & $\begin{array}{l}\text { Primer } \\
\text { (Forward/Reverse) } \\
\left(5^{\prime}-3^{\prime}\right)\end{array}$ & $\begin{array}{l}\text { Probe } \\
\text { (Wild/Mutant) } \\
(5,-3 ')\end{array}$ & $\begin{array}{l}\text { Fluorescent } \\
\text { color } \\
\text { (Wild/Mutant) }\end{array}$ \\
\hline & & & & $\begin{array}{l}\text { GTTTTGCCTTTCACATCTCAATATGT/ } \\
\text { GAAATCAGTGTTGCGATAGAATGAAG }\end{array}$ & $\begin{array}{c}\text { CTGTGCAGTGTTCTG/ } \\
\text { ATATGTGCAGAATATATGCC }\end{array}$ & FAM / VIC \\
\hline
\end{tabular}


A.

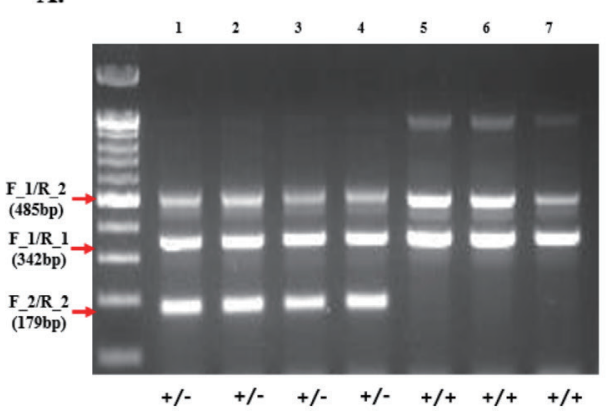

B.

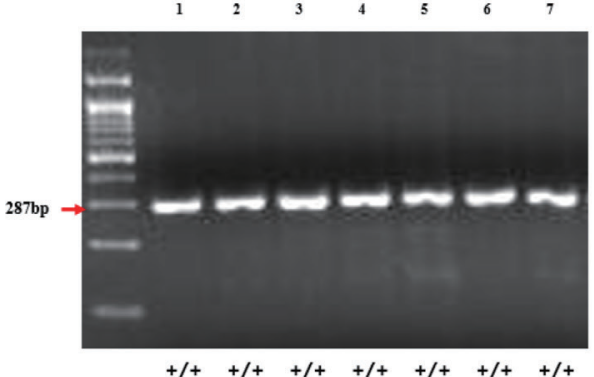

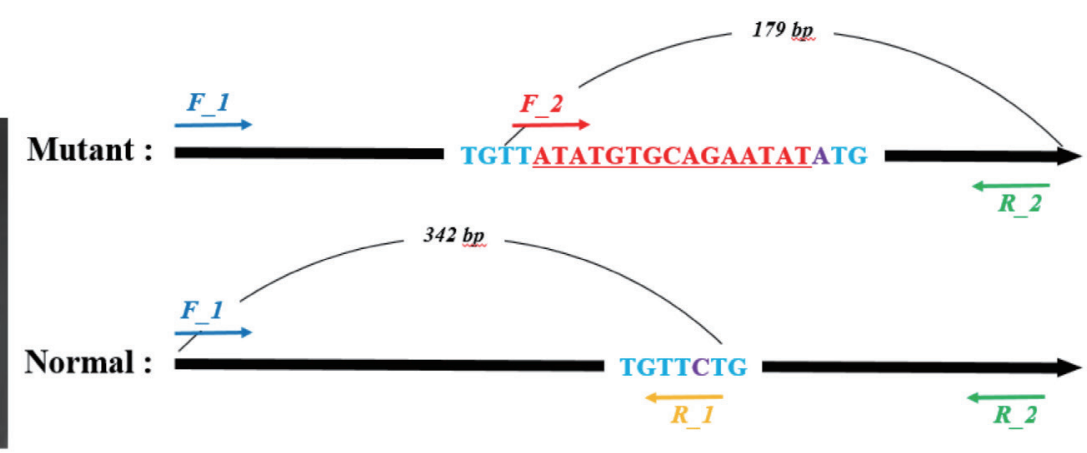

Fig. 1. The electrophoresis results for two types of F11 deficiency. (A) The carrier animals (+/-) having type I mutant showed both 485 bp and $179 \mathrm{bp}$ fragments, that resulted by $15 \mathrm{bp}$ insertional mutation. The normal animals $(+/+)$ showed both $485 \mathrm{bp}$ and $342 \mathrm{bp}$ fragments. (B) Only normal animals, showing $287 \mathrm{bp}$, for the type II deficiency were identified in this study.

affected by F11 deficiency (Ghanem et al., 2005). Holsteins with low-fertility symptoms due to F11 deficiency were calculated to have caused a total financial loss of more than $\$ 300$ per affected cow compared to normal cows (Akyuz et al., 2012).

Symptoms of F11 deficiency in Japanese black cattle tend to be mild, and there have been no reports of bleeding symptoms except for exudative hemorrhage due to castration or dehorning. Although no reports of abnormal reproductive traits have been published, F11 deficiency might lead to symptoms of low fertility; a study of Holstein cattle showed an increase in calving interval of about 50 days (Akyuz et al., 2012). In contrast, Japanese black calves with F11 deficiency exhibited growth retardation and pelvic dysplasia. These results suggest that F11 deficiency can impact calf growth and development (Takasu et al., 2005); similar symptoms can be expected in Hanwoo cattle. However, no reports to date have indicated the need for further phenotype measurement and genetic relationship studies in Hanwoo cattle to validate observations of F11 deficiency symptoms in this species. The pedigree information of the carrier animals has been traced to proven Hanwoo bulls (KPN) 872, 879, and 919, suggesting that the allele causing this disorder is in both proven bulls and cows from individual farms. Therefore, further investigation of F11 deficiency symptoms in KPN and cows is needed. In particular, we could not detect recessive homozygous animals in the population examined in this study, suggesting that F11 deficiency might be caused by a semiembryonic lethal gene, which could affect the Hanwoo population. It is necessary to accurately measure the
Hanwoo cattle F11 deficiency phenotype and its effects on productivity. In addition, the risk of declining productivity in Hanwoo cattle should be eliminated through testing for F11 deficiency both in commercial stocks and in proven bulls (KPN).

The activated partial thromboplastin (APPT) test is a conventional method used to identify F11 deficiency by measuring F11 activity (Gentry et al., 1975). Although the causes of F11 deficiency in Holstein and Japanese black cattle are different, the range of F11 activity between normal and carrier animals overlaps in both varieties (Kunieda et al., 2005; Liptrap et al., 1995). Therefore, the diagnosis of F11 deficiency through APPT makes it difficult to determine the carrier animals; this situation is also expected to affect F11 diagnosis in the Hanwoo cattle population. Furthermore, although PCR amplification is a basic and intuitive method to identify F11 deficiency, it requires approximately 6 hours. Therefore, we performed TaqMan assay genotyping as a new method for accurate identification of carrier and affected animals with F11 deficiency.

The results with Hanwoo cattle showed that 1,981 of 2,043 animals (96.97\%) were identified as normal, and $62(3.03 \%)$ as heterozygous animals for the Type I F11 deficiency. In contrast, no F11 deficiency-affected animals (recessive homozygous) were identified. Thus, the gene frequency for F11 deficiency was 1.51\% (Table 2).

We also compared the genotype results of various conditions to overcome difficulties in identifying genotypes (i.e., carrier and normal in the current study) that may occur in the field. There were two main objectives 
in designing this study. The first was to confirm whether the minimum genomic DNA concentration required for genotyping is identified by clear separation (Figure 2C). DNA was were diluted 10, 20, 30, 40, 50, and 60 times with $5 \mathrm{ng} / \mu \mathrm{L}$ of DNA at the initial concentration for efficient testing of the method. The results were the same for all dilution conditions: clearly separated genotypes between normal (orange circle) and carrier animals (green triangle) (Figure 2). Furthermore, these results confirmed that F11 deficiency can be identified using a $60 \times$ dilution of $5 \mathrm{ng}$ gDNA (roughly $83.3 \mathrm{pg}$ ). The second objective was to reduce the time required for $\mathrm{F} 11$ deficiency genotyping. In this experiment, we used the PCR reagent to skip the routine DNA extraction step, reducing the time required for DNA extraction. As a result, the total amount of time required to identify F11 deficiency from the blood sample was only about 2 hours (Figure 2B). The TaqMan assay genotyping method for
F11 deficiency identification was able to clearly detect both affected and carrier animals and also significantly reduced the time and the total amount of genomic DNA required for mutant allele detection.

This study is the first report of the presence of a Type I mutation for F11 deficiency in Hanwoo cattle, and we propose TaqMan assay genotyping as an efficient method for the identification of F11 deficiency. Our results can be used to improve the efficiency of Hanwoo cattle breeding programs in the future.

\section{AUTHOR CONTRIBUTIONS}

Sung Hyun CHO, Performed experiment, data analysis, manuscript writing.

Dongwon SEO, Ph. D; Experimental design, manuscript writing.

Onolragchaa GANBOLD, Performed experiment,

Table 2. Number of Hanwoo animals identified in each genotype for the F11 deficiency in three geographical locations in Korea

\begin{tabular}{cccccc}
\hline \multirow{2}{*}{ Location in Korea } & $\begin{array}{c}\text { Total No of } \\
\text { Animal }\end{array}$ & \multicolumn{2}{c}{ Number of animals in each Genotype } & \multicolumn{2}{c}{$\begin{array}{c}\text { mutant allele } \\
\text { frequency } \\
(\%)\end{array}$} \\
\cline { 3 - 5 } Yeongam & 776 & Normal & Carrier & Mutant & 1.5 \\
Haman & 822 & 792 & 24 & 0 & 1.6 \\
Yanggu & 445 & 433 & 12 & 0 & 1.3 \\
\hline Total & 2,043 & 1,981 & 62 & 0 & 1.5 \\
\hline
\end{tabular}
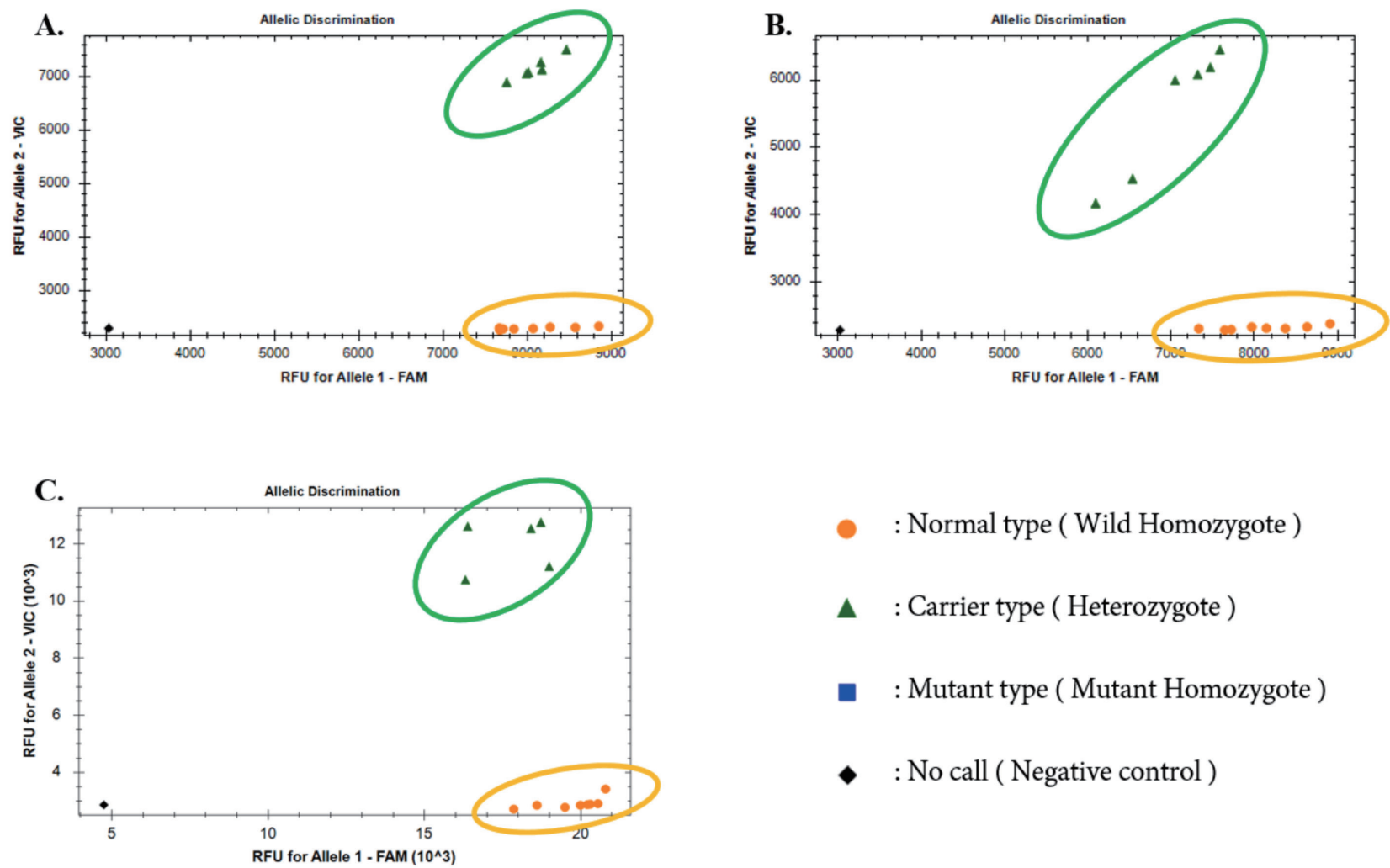

: Normal type ( Wild Homozygote )

$\Delta \quad$ : Carrier type ( Heterozygote )

- : Mutant type ( Mutant Homozygote )

$\checkmark \quad$ : No call ( Negative control)

Fig. 2. The results of three different experiments using the F11 Taq Man assay showed the same results. (A) 5 ng diluted DNA. (B) The results using Direct PCR Reagent for saving experiment time. (C) Experiment using roughly 83.3 pg DNA indicates the same results compared with diluted 5 ng of DNA concentration. 
data analysis.

$\mathrm{Nu}$ Ri CHOI, Ph. D; Performed experiment.

Prabuddha MANJULA, Performed experiment.

Shil JIN, Ph. D; Performed experiment.

Seung Hwan LEE, Ph. D; Manuscript editing.

Nobuhiko YAMAUCHI, Ph. D; Manuscript editing.

Takafumi GOTOH, Ph. D; Manuscript editing.

Jun Heon LEE, Ph. D; Experimental design, manuscript editing.

\section{AUTHOR DISCLOSURE STATEMENT}

None of the authors have any competing financial interests to declare.

\section{ACKNOWLEDGEMENT}

This work was supported by research fund of Chungnam National University.

\section{REFERENCES}

Akyuz, B., S. Sariozkan and D. Bayram 2012 Factor XI mutation in normally fertile and repeat breeding Holstein cows in the Middle Anatolian region of Turkey: a financial approach. Anim. Prod. Sci., 52: 1042-1045

Baglia, F., B. Jameson and P. Walsh 1990 Localization of the high molecular weight kininogen binding site in the heavy chain of human factor XI to amino acids phenylalanine 56 through serine 86. J. Biol. Chem., 265: 4149-4154

Baglia, F., B. Jameson and P. Walsh 1993 Identification and characterization of a binding site for factor XIIa in the Apple 4 domain of coagulation factor XI. J. Biol. Chem., 268: 38383844

Baglia, F. A. and P. N. Walsh 1996 A binding site for thrombin in the apple 1 domain of factor XI. J. Biol. Chem., 271: 36523658

Bouma, B. N. and J. H. Griffin 1977 Human blood coagulation factor XI. Purification, properties, and mechanism of activation by activated factor XII. J. Biol. Chem., 252: 6432-6437
Chung, H. J., S. L. Yu, B. C. Sang and J. H. Lee 2005 A Fundamental Genetic Study for Identifying Band 3 and CHS Genetic Diseases in Korean Cattle (Hanwoo). J. Agri. Sci. Chungnam Nat'l Univ., 32: 53-61

Dodds, W. J. and J. E. Kull 1971 Canine factor XI (plasma thromboplastin antecedent) deficiency. J. Lab. Clin. Med., 78: 746752

Gentry, P., S. Crane and F. Lotz 1975 Factor XI (plasma thromboplastin antecedent) deficiency in cattle. Canadian Vet. J., 16: 160

Ghanem, M. E., M. Nishibori, T. Nakao, K. Nakatani and M. Akita 2005 Factor XI mutation in a Holstein cow with repeat breeding in Japan. J. Vet. Med. Sci., 67: 713-715

Kim, K. S., J. S. Yeo and C. B. Choi 2002 Genetic diversity of north-east Asian cattle based on microsatellite data. Anim. Genet., 33: 201-204

Kociba, G. J., O. Ratnoff, W. Loeb, R. Wall and L. E. Heider, 1969 Bovine plasma thromboplastin antecedent (Factor XI) deficiency. J. Lab. Clin. Med., 74: 37-41

Kunieda, M., T. Tsuji, A. R. Abbasi, M. Khalaj, M. Ikeda, K. Miyadera, H. Ogawa and T. Kunieda 2005 An insertion mutation of the bovine F11 gene is responsible for factor XI deficiency in Japanese black cattle. Mamm. Genome, 16: 383-389

Lim, K. S., B. H. Park, T. J. Choi, D. Lim and Y. M. Cho 2016 Carrier testing for autosomal recessive hereditary disorder in Korean proven bulls. J. Biomed. Trans. Res., 17: 85-90

Lin, B. Z., S. Sasazaki and H. Mannen 2010 Genetic diversity and structure in Bos taurus and Bos indicus populations analyzed by SNP markers. Anim. Sci. J., 81: 281-289

Liptrap, R., P. Gentry, M. Ross and E. Cummings 1995 Preliminary findings of altered follicular activity in Holstein cows with coagulation factor XI deficiency. Vet. Res. Commum., 19: 463-471

Marron, B. M., J. L. Robinson, P. A. Gentry and J. E. Beever 2004 Identification of a mutation associated with factor XI deficiency in Holstein cattle. Anim. Genet., 35: 454-456

Sun, Y. and D. Gailani 1996. Identification of a factor IX binding site on the third apple domain of activated factor XI. J. Biol. Chem., 271: 29023-29028

Takasu, M., E. Takeda, N. Nishii, Y. Ohba, S. Maeda, K. Miyazawa, H. Ogawa and H. Kitagawa 2005 Japanese black calf with growth retardation showing prolonged Active Partial Thromboplastin Time. J. Jpn. Vet. Med. Assoc., 58: 820-822 